\section{ECONOMICS}

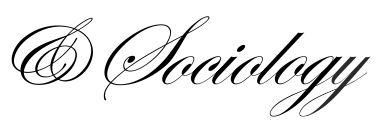

Okulicz-Kozaryn, A., \& Morawski, L. (2021). A similar effect of volunteering and pensions on subjective wellbeing of elderly. Economics and Sociology, 14(2), 11-39. doi:10.14254/2071-789X.2021/14-2/1

\title{
A SIMILAR EFFECT OF VOLUNTEERING AND PENSIONS ON SUBJECTIVE WELLBEING OF ELDERLY
}

\author{
Adam Okulicz-Kozaryn \\ Rutgers University, \\ Camden, USA \\ E-mail: \\ adam.okulicz.kozaryn@gmail.com
}

\author{
Leszek Morawski \\ Faculty of Economic Sciences, \\ University of Warsaw, \\ Warsaw, Poland \\ E-mail: l.morawski@,uw.edu.pl
}

\author{
Received: October, 2020 \\ 1st Revision: March, 2021 \\ Accepted: May, 2021
}

DOI: $10.14254 / 2071-$

789X.2021/14-2/1

JEL Classification: 130

\begin{abstract}
We study the effect of pensions and volunteering on subjective wellbeing (SWB) of elderly using the latest wave 6 of Survey of Health, Aging and Retirement in Europe (SHARE). This is the first study to consider pensions and volunteering simultaneously as determinants of SWB among elderly. We find that the effect of volunteering on SWB is not much smaller or indeed about as large as that of pensions. The most SWB is associated with volunteering about every week, but there is already a substantial effect even if one volunteers only about every month. We also find that the higher the income or wealth, but not pension, the lower the effect of volunteering - there may be higher opportunity cost for richer people to engage in volunteering. High European pensions may be unsustainable in the long run - we argue that promotion of volunteering is one way to increase elderly's subjective wellbeing amidst tightening budgets.
\end{abstract}

Keywords: Subjective Wellbeing (SWB), Life Satisfaction, Happiness, Aging, Elderly, Volunteering, Social Transfers, Social Capital, Survey of Health Aging and Retirement in Europe (SHARE)

\section{Introduction}

Population aging will be the key issue in this century, and perhaps even in the third millennium (Stolnitz, 1992). Specifically, there are growing concerns about sustainability of pensions and health care (Jürges \& van Soest, 2012). The problem of aging is clear in many European countries, e.g., in Germany, Europe's most populous country, and there is clearly a need for social science research to address aging as one of the most important challenges of our times (Vaupel \& Loichinger, 2006). Amidst growing concerns about sustainability of pensions and health care, there is much need to investigate alternative ways of sustaining and increasing the wellbeing of the elderly. In present study we are especially interested in whether the effect of volunteering is comparable to that of pensions.

Volunteering has been advocated by the United Nations, American and European governments as a way to engage people in their local communities and improve social capital, with the potential for public health benefits such as improved health and overall wellbeing 
(Jenkinson et al., 2013). Promotion of volunteering could be an alternative strategy to sustained social transfers in an effort to achieve wellbeing. Other strategies include (Ferring \& Boll, 2010, sec. 2.4.5): psychotherapeutic interventions (cognitive-behavioural therapy, relaxation, reminiscence), psycho-educational ones (such as social activity programmes), and cognitivebehavioural - as well control-enhancing strategies.

Better understanding of the determinants of SWB enables us to evaluate and possibly reform present retirement institutions, such as pension programs, as well as potentially generate new institutions to meet the demands of a rapidly increasing retirement population. SWB can serve as a yardstick to evaluate relative strength and net effect from each factor. In the present study, we will use SWB to measure net effects of economic capital (pensions) and social capital (volunteering) - we will control for both in one model. ${ }^{1}$

There is a growing recognition of subjective well-being and quality of life indicators (Okulicz-Kozaryn, 2016). Traditional measures of development, such as income, production, or consumption are too simplistic. They do not capture the overall progress of our civilization. For instance, gross domestic product increases when there is traffic congestion, but clearly that is not progress. But even an increase in household income does not necessarily create progress if there is growing income inequality. Other important ingredients of overall development and progress such as discretionary time, mental and physical health are not captured by monetary measures. We will capture overall progress by using SWB yardstick.

Studies focusing on elderly and their wellbeing, either miss social transfers or volunteering (they do not examine them simultaneously), and they often measure only specific domains of wellbeing, not overall wellbeing. We hypothesize some degree of tradeoff or substitution between social capital and social transfers. The more social capital, especially in the form of volunteering, the lower the need for social transfers to achieve SWB.

H1: When considered simultaneously, both pensions and volunteering increase SWB.

Employed or low income elderly may have less opportunity for volunteering than those not working full time and with enough income to make a living. Arguably, to afford volunteering you have to have basic income. Only then can you satisfy higher needs on the Maslow pyramid such as the need to belong (Maslow 1987). On the other hand, the high earners and wealthy have higher opportunity $\operatorname{cost}^{2}-$ they should rather donate money than time. Clearly, a high earner has a high opportunity cost-she would contribute more by working more and then donating rather than volunteering. But also so does a wealthy person has an opportunity costshe could spend her time investing her wealth rather than volunteering, and then donate part of the earned income. Borgonovi (2008) found that low status is associated with low SWB only among those who do not volunteer - volunteering might contribute to SWB by increasing empathy, shifting aspirations and by moving the reference group to the relatively worse-off.

We think that volunteering may be especially conducive for wellbeing among less welloff elderly. If one has plenty of economic resources, one may need or prefer volunteering less and also have higher opportunity cost associated with volunteering.

\footnotetext{
${ }^{1}$ We also control for other economic capital than pensions, e.g., income and wealth; and we control for other social capital than volunteering, e.g., attending educational or training course, playing cards).

2 Oxford's dictionary of economics defines opportunity cost as "The cost of something in terms of an opportunity forgone. Opportunity cost is given by the benefits that could have been obtained by choosing the best alternative opportunity. For example, for a farmer the opportunity cost of growing wheat is given by what they would have earned if they had grown barley, assuming barley is the best alternative." http://www.oxfordreference.com/search?q=opportunity++cost\&searchBtn=Search\&isQuickSearch=true.
} 
H2a: The higher the income, the less benefit from volunteering in SWB.

$\mathrm{H} 2 \mathrm{~b}$ : The higher the wealth, the less benefit from volunteering in SWB.

$\mathrm{H} 2 \mathrm{c}$ : The higher the pensions, the less benefit from volunteering in SWB.

The broad goal of the present research is to explore volunteering as a viable strategy to improve elderly wellbeing. Specifically, we are interested in the relative strength of the effect of volunteering on SWB as compared to that of income, wealth, and pensions. We are using wave 6 of Survey of Health, Aging and Retirement in Europe (SHARE). Subjective wellbeing (SWB) is the dependent variable; volunteering, income, wealth, and pensions are the main independent variables of interest; and we control for a typical set of SWB predictors.

\section{Subjective wellbeing (SWB)}

A brief overview of the concept of subjective wellbeing (SWB) is provided in McMahon (2005), and a full definition and overview across human history is provided in McMahon (2006). The wellbeing concept is used in current socio-economic research (e.g., Bilan et al., 2020, Cannas et al., 2019), including research on elderly (e.g., D’Silva \& Samah, 2018).

SWB is multidimensional. Hedonic dimension is about prevalence of pleasure over pain. Eudaimonic dimension is about "good life." There is effective momentary happiness, and there is cognitive evaluative life satisfaction. There is some overlap between the two, and there even more dimensions. Notably there are domain satisfactions such as social/community, economic/financial, and social/family. In other words, overall human wellbeing or life satisfaction can be conceptualized as consisting of domain satisfactions that make up the overall satisfaction (Diener, 2009, Diener \& Seligman, 2004, Veenhoven, 2008, Kahneman et al., 1999, Campbell et al., 1976).

We will use two measures that are overall or all-inclusive, as opposed to confined to a domain or domains, and are mostly cognitive and evaluative as opposed to effective and momentary: single item life satisfaction question and CASP scale (Hyde et al., 2003a, 2015). Life satisfaction is rather hedonic. CASP scale, on the other hand, is more comprehensive and also includes some eudaimonic items as discussed in the data section.

CASP can be conceptualized as Control, Autonomy, Self-realization, and Pleasure (Hyde et al., 2003a, 2015). CASP is often referred to as quality of life (QOL) measure. But it is probably better understood as SWB measure because QOL measures are rather objective (Okulicz-Kozaryn, 2013, Okulicz-Kozaryn \& Valente, 2019). Vanhoutte (2012, 2014) also considers CASP to be SWB measure.

One could take volunteer process perspective and approach volunteering as having antecedents, consequences, but also the middle category-the experience of volunteering (Wilson 2012b). We study here SWB as a consequence of volunteering and our measures of SWB are well suited for it.

The self-reported and subjective SWB measures are reliable (precision varies) and valid (Myers, 2000, Di Tella \& MacCulloch, 2006, Diener, 2009).

\section{Volunteering}

Wilson ( 2012b, p. 177) provides a useful overview of definitions. Literature often defines volunteering as "freely chosen and deliberate helping activities that extend over time, are engaged in without expectation of reward or other compensation and often through formal organizations, and that are performed on behalf of causes or individuals who desire assistance." A parsimonious definition is "unpaid help given to another person not a member of one's 
family." The key part of definition is altruism. Wilson (2012b) in his review lists many predictors of volunteering. For instance, volunteering earlier in life predicts volunteering later in life and increased purpose in life.

Elderly often are an unused productive capacity. The literature agrees that volunteering is a productive aging strategy (e.g., Wilson, 2012b, Hank \& Erlinghagen, 2009). Reward experienced from helping others is observed in diverse cultural and economic contexts and it may be part of human nature (Aknin et al., 2013).

Anderson et al. (2014) is a recent comprehensive review of benefits of volunteering among seniors: volunteering is associated with reduced symptoms of depression, better selfreported health, fewer functional limitations, and lower mortality. The protective benefits associated with volunteering are amplified if volunteers feel reciprocity (i.e., their work is appreciated and "matters"), contribute their time for prosocial reasons, and make a moderate but not excessive commitment to volunteering. Indeed, volunteering can have negative effects, especially if done in disaster situations (earthquakes, etc) or towards people in very difficult situations (Ebola, etc) (Wilson, 2012b). It helps, on the other hand, if one volunteers for extrinsic as opposed to intrinsic reasons.

\section{Pensions}

Many studies at person level have focused on income and found that personal income increases SWB at least with diminishing returns (Okulicz-Kozaryn \& Mazelis, 2016, Kahneman \& Deaton, 2010, Frijters et al., 2004, Kushlev et al., 2015, Dolan et al., 2008, Veenhoven, 2012). Yet, this line of happiness research about personal income tends to overlook pensions and other social transfers-main reasons are probably twofold: researchers tend to focus solely on income often following Easterlin paradox (Easterlin et al., 2010) and most data do not allow for fine-grained measurement of social transfers. There are exceptions, however. Notably, there is a recent experimental study (Oswald, 2014). Poor British were given additional help from the government (training and money), they were followed for several years, and at the end, the ones that received additional money were not richer or happier than those who did not receive the help, if anything, they were worse off. Still, there is no study considering simultaneously social transfers including pensions and social capital including volunteering.

As a sidenote: there is an abundant literature about the effect of social transfers on SWB as recently reviewed in Okulicz-Kozaryn et al. (2014). Political scientists tend to focus on social transfers at country level (Alvarez-Diaz et al., 2009, Pacek \& Radcliff, 2008a, Radcliff, 2013, Pacek \& Radcliff, 2008b, Radcliff, 2001, Bok, 2010). A popular measure is a so called "decommodification." Decommodification mostly means good pensions, sickness benefits, and unemployment compensation-measurement is described in Scruggs and Allan (2006). Instead of using such aggregate country level measurement of social transfers, we zoom in at person level. ${ }^{3}$ An obvious question is how much welfare there is in pensions, i.e. how much a worker contributes to her pension and how much is contributed from elsewhere? See appendix, section "welfare contributions" for a breakdown.

\footnotetext{
3 There are surprisingly different relationships between SWB and its predictors depending on the level of analysis (Ashkanasy 2011), and research implications can be misguided when taken from only one level of analysis (Klein \& Kozlowski, 2000).
} 


\section{Predicting SWB}

Our contribution is that we investigate SWB among elderly across multiple countries using large representative samples and focus on volunteering and pensions simultaneously. Studies focusing on elderly and their wellbeing, either miss pensions or volunteering (they do not examine them simultaneously), and they often measure only specific domains of wellbeing. For instance, Bender (2012) overlooks volunteering and studies retirement satisfaction: "All in all, would you say that your retirement has turned out to be very satisfying, moderately satisfying, or not at all satisfying?" Butrica and Schaner (2005) also study retirement satisfaction, do focus on volunteering (and interestingly suggest that volunteering in excess of $1 \mathrm{k}$ hours per year does not help with satisfaction), but miss pensions. All studies in a recent issue of Social Indicators Research (Jürges \& van Soest, 2012) dedicated to aging and wellbeing used other dependent variable than SWB, except one (Angelini et al., 2012), which again, did not focus on pensions and volunteering. Studies that focus on SWB and retirement also either miss pensions or volunteering (Dingemans \& Henkens, 2014, 2015, Nikolova \& Graham, 2014, Angelini et al., 2012). Many of such studies are more than ten years old and carried out in the US (Wheeler et al., 1998, Ferring \& Boll, 2010). Volunteering and pensions are very different in the US and Europe (De Tocqueville, 2003, Fischer, 2010, Alesina et al., 2005, 2001, Lipset \& Marks, 2000).

Volunteering predicts SWB (Dolan et al. 2008, Jenkinson et al., 2013). What could be the causal pathway, how could volunteering cause SWB? Being a volunteer transforms one's perceptions of herself, emotions, and knowledge of the world (Wilson, 2012b). Volunteering boosts one's self esteem, buffers against stress, and enhances mastery experiences (Wilson, 2012b). Volunteering is argued to cause SWB (Meier \& Stutzer, 2008a, Borgonovi, 2008). For instance, low status is associated with low SWB only among those who do not volunteervolunteering might contribute to SWB by increasing empathy, shifting aspirations and by moving the reference group to the relatively worse-off (Borgonovi, 2008). There are, of course, other causal pathways possible. And we do not focus on causality in this correlational study.

Volunteering predicts happiness among elderly (in New Zealand) and the effect is moderated by economic resources: poor benefit more from volunteering than rich (Dulin et al. 2012). And elderly may benefit more than younger people (Van Willigen, 2000, Wahrendorf et al., 2006). This may also indicate that acting in a social role beyond employment is beneficial for wellbeing.

\section{Data}

We use the Survey of Health, Aging and Retirement in Europe (SHARE) (BörschSupan, 2017). SHARE is a cross-country panel dataset containing more than 50,000 persons aged 50+. We use Wave 6 release 6.0 conducted in 2015, which has the largest number of countries of all waves. For robustness, we have also used wave 4 and obtained similar resultsresults are available upon request.

Especially earlier waves have few countries - SHARE sample grew substantially over time and its country coverage almost doubled. Another advantage of wave 6 is that data were collected in just one year (2015), while in earlier waves data were collected over longer spansseasonality may be a problem in studies using earlier waves of the dataset.

Key variables are discussed below and all variables are listed in appendix along with their distributions and module source. Most of the variables are from the imputed module; we have used other modules only when variable was not available in the imputed module. For instance, social capital including volunteering comes from the Activities (AC) module. 
We use $\mathrm{MN}$ and $\mathrm{CF}$ modules to exclude elderly in retirement homes and proxy observations. We drop people who were in nursing homes $\tilde{(}(1 \%)$ : such persons typically do not have opportunity for volunteering. We also drop proxy respondents ( $5 \%)$ and only retain main participants. Respondents younger than 50 (about $2 \%$ of the sample) are dropped.

All dollar amounts are PPP (Purchasing Power Parity) adjusted. Arguably what matters for SWB is rather what money buys, not its numeric value.

SHARE contains typical life satisfaction question: "On a scale from 0 to 10 where 0 means completely dissatisfied and 10 means completely satisfied, how satisfied are you with your life?" The survey-based life satisfaction measure is closely correlated with similar objective measures such as brain activity (Layard 2005). We also use CASP scale to measure subjective wellbeing. Life satisfaction and CASP are correlated at .6. SHARE contains a shortened 12-item version that has desirable psychometric properties (Knesbeck et al. 2005). CASP differs from SWB: it factors in accomplishment and fulfillment, a concept related to Maslow's hierarchy of needs (Maslow 1987). Such measure is very relevant at an older age when accomplishment and fulfillment are more relevant. CASP is widely used-see for instance Pérez-Rojo et al. (2017), Amit and Litwin (2010), Hyde et al. (2003a, 2015, 2003b), Kim et al. (2015).

CASP contains variables listed in table 1 . We used factor analysis to make CASP scale (varimax rotation). Cronbach's alpha measuring its internal consistency reliability is .82. An index from factor analysis is more meaningful than an index simply made by adding the components: factor analysis weights components based on their fit or consistency-components that overlap more are given more weight. ${ }^{4}$

Table 1. Factor loadings (with varimax rotation) for survey items in CASP scale. Cronbach's alpha is .82

\begin{tabular}{cl}
\hline-0.50 & My age prevents me from doing the things I would like to \\
\hline-0.52 & I feel that what happens to me is out of my control \\
\hline-0.57 & I feel left out of things \\
\hline 0.45 & I can do the things that I want to do \\
\hline-0.19 & Family responsibilities prevent me from doing what I want to do \\
\hline-0.38 & Shortage of money stops me from doing the things I want to do \\
\hline 0.58 & I look forward to each day \\
\hline 0.67 & I feel that my life has meaning \\
\hline 0.49 & On balance, I look back on my life with a sense of happiness \\
\hline 0.68 & I feel full of energy these days \\
\hline 0.72 & I feel that life is full of opportunities \\
\hline
\end{tabular}

Source: own compilation

Social transfers and social capital (especially volunteering) are main independent variables of interest. We measure social transfers directly as money amounts. The key variable, pension, is measured as a sum of annual old age, early retirement pensions, survivor and war pension, annual private occupational pensions and other regular payments from private pensions.

We also control for disability, unemployment benefits and social assistance. It is important to separate these variables. Disability, unemployment benefits and social assistance

\footnotetext{
${ }^{4}$ Per CASP and factor analysis see Kim et al. (2015); per use of factor analysis and Cronbach's alpha in research see: Senlier et al. (2009), Proctor (2006).
} 
may decrease SWB as they indicate disadvantaged status, and sometimes social stigma. Note that we also control for disability and employment status.

Volunteering is measured using the AC module in two ways: "Please look at card 34: which of the activities listed on this card - if any - have you done in the past twelve months?" “Done voluntary or charity work" coded as $0=$ 'no' or $1=$ 'yes' (ac035d1).

The second item reads: "How often in the past twelve months did you [do voluntary or charity work]?" on scale from 1='less often' to 4='almost daily' (ac036_1). We will also control for other forms of social capital such as relationships with other people: family members, friends, neighbors, or other acquaintances. It is important to think about what relates to volunteering-these variables may be confounders, and failure to control for them may result in bias in volunteering estimates. We control for variables related to volunteering: age, lack of resources (free time), gender, education, labor force status, income, and family of origin (Wilson 2012a, Haski-Leventhal 2009).

The control for key predictors of SWB: income and unemployment ( Di Tella et al. 2001b, 2001a, Di Tella and MacCulloch 2006), social capital and health (Blanchflower and Oswald 2011, Dolan et al. 2008, Bonsang and van Soest 2012). We will also control for other predictors of SWB as suggested in the literature. In the context of present study we think that the following variables are especially important: marital status (e.g., Myers 2000, Diener and Seligman 2004), and age (Ferring and Boll 2010). We also include having grandchildren as a control variable-grandchildren not only can affect elderly SWB, but also time available to volunteering. We also follow gerontological literature in our choice of controls (e.g., Meier and Stutzer 2008a, Bonsang and van Soest 2012, Bender 2012, Ferring and Boll 2010), and while we are unable to control for retirement voluntariness, we do control for disability.

Finally, at country level, we use fixed effects to account for country-level heterogeneity. European countries are quite different and so volunteering (and other variables) mean something different across countries. Hence, we include a dummy for each country-it would pick up everything that is specific about the given country. This study's focus is the overall relationship between social capital, social transfers and SWB. In a followup paper, we will focus on cross-national differences in these relationships.

The hypotheses are tested using a regression approach using survey weights. Happiness is an ordinal variable, and hence, it should be modeled using ordinal regression. We will use ordinary least squares (OLS), however. We know that in case of happiness, OLS performs well and results tend to be similar to those from discrete models (Ferrer-i-Carbonell \& Frijters, 2004, Blanchflower \& Oswald, 2011). OLS estimates have an advantage--they are easier to interpret. ${ }^{5}$

\section{Results}

For basic exploratory models see appendix, section "baseline regression results." Here, we focus on final models including pensions and volunteering simultaneously to test hypothesis.

In table $2^{6}$ we include both pensions (and other social transfers) and volunteering (and other social capital), to see how they substitute/complement each other when they both are included in the same model. We are interested in what is the net effect of each. Column c1 regresses SWB on volunteering (and other forms of social capital) and pension. Column c2 adds other social transfers and full set of controls and estimates are much attenuated on both volunteering and pension, but they remain about the same, now pension being stronger. Results

\footnotetext{
${ }^{5}$ Per OLS and discrete models see Gujarati (2002).

${ }^{6}$ For methodological discussion of beta (fully standardized) coefficients see Gujarati (2002).
} 
for CASP are more statistically significant and have stronger effect sizes-arguably CASP captures SWB better than life satisfaction measure as it uses multiple items. A comforting result is that CASP models (c3 and c4) show the same patterns as in previous life satisfaction models. In full model (c4), the effect of pension is about the same as the effect of volunteering. Hence, given that CASP is a preferable measure of SWB, our overall conclusion is that volunteering has about the same effect as pensions. This is the key point and finding of this study.

Also, note that volunteering only "almost every month" already contributes significantly to SWB. "Almost every week" contributes most to SWB, even more than volunteering "almost every day" in c1 and c3. A curvilinear relationship is common in the literature-there may be excessive overcommitment and "emphatic over-arousal" (Wilson, 2012b).

Table 2. OLS of SWB (life satisfaction and CASP) on volunteering and pensions. Beta (fully standardized) coefficients reported. All models include country dummies

\begin{tabular}{|c|c|c|c|c|}
\hline & $\begin{array}{c}\text { Life } \\
\text { satisfaction }\end{array}$ & $\begin{array}{c}\text { Life } \\
\text { satisfaction }\end{array}$ & CASP & CASP \\
\hline & $\mathrm{c} 1$ & c2 & c3 & $\mathrm{c} 4$ \\
\hline \multicolumn{5}{|l|}{ voluntary or charity work: } \\
\hline -less often & -0.00 & -0.01 & $0.02 *$ & 0.01 \\
\hline -almost every month & $0.02 * *$ & 0.01 & $0.05 * * *$ & $0.02 * * *$ \\
\hline -almost every week & $0.03 * * *$ & $0.01 *$ & $0.05 * * *$ & $0.03 * * *$ \\
\hline -almost every day & $0.02 * *$ & $0.01 *$ & $0.04 * * *$ & $0.03 * * *$ \\
\hline pension PPP '000 & $0.04 * *$ & $0.03 * *$ & 0.01 & $0.03 * *$ \\
\hline attended an educational or training course & $0.03 * * *$ & 0.01 & $0.08 * * *$ & $0.02 * *$ \\
\hline gone to a sport, social or other kind of club & $0.08 * * *$ & $0.03 * * *$ & $0.12 * * *$ & $0.05 * * *$ \\
\hline $\begin{array}{l}\text { taken part in a political or community-related } \\
\text { organization }\end{array}$ & 0.01 & -0.00 & $0.03 * * *$ & $0.01+$ \\
\hline read books, magazines or newspapers & $0.11 * * *$ & $0.07 * * *$ & $0.16 * * *$ & $0.10 * * *$ \\
\hline $\begin{array}{l}\text { did word or number games (crossword } \\
\text { puzzles/Sudoku...) }\end{array}$ & $0.02+$ & $0.02+$ & $0.03 * * *$ & $0.03 * * *$ \\
\hline played cards or games such as chess & $0.03 * * *$ & $0.03 * *$ & $0.04 * * *$ & $0.03 * * *$ \\
\hline labor income PPP '000 & & $0.04 * * *$ & & $0.03 * * *$ \\
\hline unemployment benefits PPP '000 & & -0.02 & & -0.00 \\
\hline social assistance PPP '000 & & 0.00 & & -0.01 \\
\hline disability/sickness benefits PPP ’000 & & -0.00 & & 0.01 \\
\hline household net worth PPP '000 & & $0.04 * * *$ & & $0.04 * * *$ \\
\hline male & & -0.01 & & 0.01 \\
\hline married and living together & & $0.14 * * *$ & & $0.07 * * *$ \\
\hline employed & & 0.02 & & $0.04 * * *$ \\
\hline age & & $0.36^{*}$ & & $0.83 * * *$ \\
\hline age2 & & -0.20 & & $-0.81 * * *$ \\
\hline years of education & & -0.00 & & $0.03 * * *$ \\
\hline number of grandchildren & & $0.01+$ & & $0.02 * *$ \\
\hline permanently sick or disabled & & $-0.04 *$ & & $-0.03 *$ \\
\hline mobility limitations & & $-0.13 * * *$ & & $-0.22 * * *$ \\
\hline self reported health & & $0.25^{* * *}$ & & $0.29 * * *$ \\
\hline $\mathrm{N}$ & 62959 & 62959 & 61487 & 61487 \\
\hline
\end{tabular}

$+\mathrm{p}<0.10 * \mathrm{p}<0.05 * * \mathrm{p}<0.01 * * * \mathrm{p}<0.001$, robust

std err

Source: own compilation 


\section{More volunteering, more SWB, but at the same rate for everyone?}

We turn to testing a set of hypotheses: whether the effect of volunteering on SWB differs by income, wealth, and pension.

In this last part of the analysis we try to answer a question whether volunteering can be more useful for certain socio economic groups. Earlier, to see an effect from each, we have separated streams of income, and focused on pensions. Now, we use total household income measure to capture its entirety-we would like to know the effect of volunteering by different total household income levels. We will also be using wealth stock measure: household net worth. ${ }^{7}$ What matters for one's SWB is not only how much she makes but how much she has. We start by defining groups according to income, wealth, and pensions. Note the crosscorrelations between these variables in table 3: income and wealth are moderately correlated, income and pension are even more highly correlated, while correlation between wealth and pension is low.

Table 3. Cross-correlations table. All correlations are significant at .001 level of significance

\begin{tabular}{lccc}
\hline & total hh income & household net worth & pension \\
\hline total hh income & 1.00 & & \\
\hline household net worth & 0.40 & 1.00 & \\
\hline pension & 0.62 & 0.16 & 1.0 \\
\hline
\end{tabular}

Source: own compilation

Results are shown in table 4, but when it comes to interactions, it is easier to interpret predicted values in graph 1 . The more nonvolunteer (solid line) makes or owns, the higher is her SWB-the poor and the middle class seem to benefit more from volunteering than the rich. Dulin et al. (2012) also found that poor benefit more than rich. Pensions, on the other hand, do not affect the volunteering-SWB relationship. SWB is about the same for volunteers and nonvolunteers at income of $60 \mathrm{k}$ or wealth of $600 \mathrm{k}$ for life satisfaction and at about total income of $100 \mathrm{k}$ or $1 \mathrm{~m}$ total net worth for CASP. Interestingly, the relationship with pension is flat. How can these results be explained? One explanation is that pensions do not require time (as opposed to labor income), and provide peace of mind and let one engage in volunteering as opposed to paid labor.

\footnotetext{
${ }^{7}$ For definition of this and other variables see appendix: "additional descriptive statistics."
} 
Table 4. OLS of SWB (life satisfaction and CASP) on volunteering and pensions. Unstandardized coefficients reported. All models include country dummies

\begin{tabular}{|c|c|c|c|c|c|c|}
\hline \multicolumn{7}{|c|}{ satisfactionsatisfactionsatisfaction } \\
\hline & $\mathrm{d} 1$ & $\mathrm{~d} 2$ & $\mathrm{~d} 3$ & $\mathrm{~d} 4$ & $\mathrm{~d} 5$ & $\mathrm{~d} 6$ \\
\hline volunteering/charity & $0.1199+$ & $0.1263^{*}$ & 0.0502 & $0.1536 * * *$ & $0.1419 * * *$ & $0.0994 * * *$ \\
\hline total hh income PPP '000 & $0.0026 * *$ & $0.0024 * *$ & $0.0027 * * *$ & $0.0014 * *$ & $0.0012 * *$ & $0.0012 * * *$ \\
\hline $\begin{array}{l}\text { volunteering/charity } \times \text { total hh } \\
\text { income PPP }, 000\end{array}$ & -0.0021 & & & $-0.0017 * *$ & & \\
\hline household net worth PPP '000 & $0.0002 * * *$ & $0.0003 * *$ & $0.0002 * *$ & $0.0001 * * *$ & $0.0002 * *$ & $0.0001 * * *$ \\
\hline $\begin{array}{l}\text { attended an educational or training } \\
\text { course }\end{array}$ & 0.0494 & 0.0470 & 0.0458 & $0.0592 * *$ & $0.0575 * *$ & $0.0576 * *$ \\
\hline $\begin{array}{l}\text { gone to a sport, social or other kind of } \\
\text { club }\end{array}$ & $0.1477 * * *$ & $0.1469 * * *$ & $0.1455 * * *$ & $0.1104 * * *$ & $0.1095 * * *$ & $0.1086 * * *$ \\
\hline $\begin{array}{l}\text { taken part in a political or } \\
\text { community-related organization }\end{array}$ & -0.0032 & -0.0037 & -0.0085 & $0.0524 *$ & $0.0510 *$ & $0.0485 *$ \\
\hline read books, magazines or newspapers & $0.2737 * * *$ & $0.2731 * * *$ & $0.2748 * * *$ & $0.1957 * * *$ & $0.1956 * * *$ & $0.1964 * * *$ \\
\hline $\begin{array}{l}\text { did word or number games } \\
\text { (crossword puzzles/Sudoku...) }\end{array}$ & $0.0574+$ & $0.0580+$ & $0.0581+$ & $0.0667 * * *$ & $0.0672 * * *$ & $0.0670 * * *$ \\
\hline played cards or games such as chess & $0.0956^{* *}$ & $0.0953 * *$ & $0.0964 * *$ & $0.0538 * * *$ & $0.0538 * * *$ & $0.0544 * * *$ \\
\hline male & -0.0212 & -0.0215 & -0.0208 & $0.0265^{*}$ & $0.0262 *$ & $0.0257+$ \\
\hline married anc & $0.5092 * * *$ & $0.5072 * * *$ & $0.5054 * * *$ & $0.1299 * * *$ & $0.1285 * * *$ & $0.1288 * * *$ \\
\hline employed & $0.1149 *$ & $0.1125^{*}$ & $0.1099 *$ & $0.0864 * * *$ & $0.0848 * * *$ & $0.0858 * * *$ \\
\hline age & $0.0615^{* *}$ & $0.0612 * *$ & $0.0622 * *$ & $0.0746 * * *$ & $0.0746 * * *$ & $0.0747 * * *$ \\
\hline age 2 & -0.0002 & -0.0002 & -0.0002 & $0.0005^{-}$ & $\begin{array}{c}- \\
0.0005^{*}\end{array}$ & $\begin{array}{c}- \\
0.0005 * * * \\
\end{array}$ \\
\hline year: & 0.0003 & 0.0001 & 0.0003 & $0.0063 * * *$ & $0.0062 * * *$ & $0.0062 * * *$ \\
\hline number of grandchildren & 0.0093 & $0.0094+$ & 0.0091 & $0.0072 * *$ & $0.0072 * *$ & $0.0071 * *$ \\
\hline mobility limitations & $-0.1023 * * *$ & $-0.1021 * * *$ & $-0.1025^{* * *}$ & $\begin{array}{c}- \\
0.0940 * * * \\
\end{array}$ & $0.0939 *$ & $\begin{array}{c}- \\
0.0941 * * *\end{array}$ \\
\hline permanently sick or & $-0.3684^{*}$ & $-0.3689 *$ & $-0.3703^{*}$ & $-0.1734 * *$ & $-0.1736 * *$ & $-0.1734 * *$ \\
\hline self reported health & $0.4380 * * *$ & $0.4380 * * *$ & $0.4381 * * *$ & $0.2643 * * *$ & $0.2643 * * *$ & $0.2643 * * *$ \\
\hline $\begin{array}{l}\text { volunteering/charity } \times \text { household net } \\
\text { worth PPP '000 }\end{array}$ & & $-0.0003+$ & & & $-0.0001 *$ & \\
\hline pension PPP '000 & & & -0.0010 & & & -0.0002 \\
\hline $\begin{array}{l}\text { volunteering/charity } \times \text { pension PPP } \\
` 000\end{array}$ & & & 0.0017 & & & 0.0009 \\
\hline constant & $3.2310 * * *$ & $3.2392 * * *$ & $3.2129 * * *$ & $3.4490 * * *$ & $\begin{array}{c}- \\
3.4456 * * * \\
\end{array}$ & - $3.4433 * * *$ \\
\hline $\mathrm{N}$ & 62967 & 62967 & 62967 & 61492 & 61492 & 61492 \\
\hline
\end{tabular}

$+\mathrm{p}<0.10 * \mathrm{p}<0.05 * * \mathrm{p}<0.01$

$* * * \mathrm{p}<0.001$, robust std err

Source: own compilation 

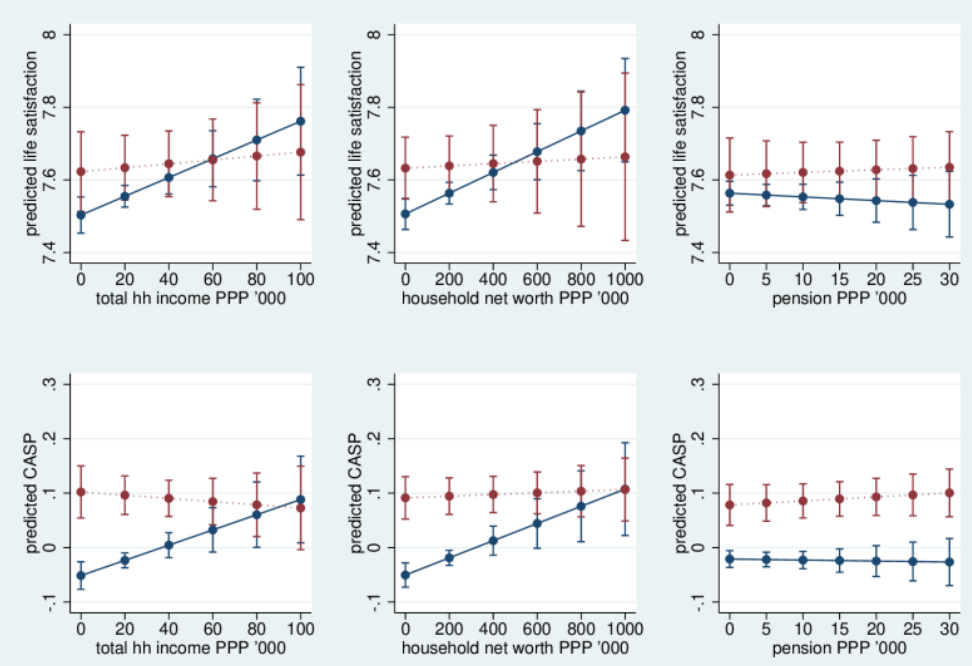

Figure 1. SWB (life satisfaction and CASP) against income, wealth, and pensions for volunteers (dotted line) and non-volunteers (solid line)

Source: own compilation

Regarding income and household net worth: clearly there is an opportunity cost. The rich could give to charity couple millions, rather than help the kids cross the street. People give what they have-rich have money, poor have time. Note that prosocial spending also contributes to SWB (Aknin et al., 2013). With pensions the relationship is flat because there is no opportunity cost-you get what you get.

More results focusing on employment status and a brief discussion of longitudinal modeling are in appendix, section "additional results."

\section{Conclusion and discussion}

It is the first study to consider pensions and volunteering simultaneously as a determinant of SWB among elderly. We found support for H1: both pensions and volunteering increase SWB. This study adds another piece of evidence to a line of research arguing that volunteering is a productive aging strategy (e.g., Wilson, 2012b, Hank \& Erlinghagen, 2009) here "productive" means increasing SWB. Our findings support the theory of elderly as an unused productive capacity and volunteering as a productive aging strategy (e.g., Wilson, 2012b, Hank \& Erlinghagen, 2009, Aknin et al., 2013).

Importantly, when considered simultaneously, pensions and volunteering have about the same effect on SWB. This is a surprising result. One would be surprised that pensions, a key economic factor in wellbeing of elderly, have only as large effect as that of volunteering. This is our key finding: the effect of volunteering is surprisingly strong-about the same as the effect of pensions. Again, clearly, one would expect pensions to have more bearing on one's wellbeing than a mere act of volunteering. Surely, volunteering, or anything else for that matter, cannot be a complete alternative or a substitute to pension. One needs to be able to afford necessities. But it can be a significant complement and it can arguably tradeoff some of the stagnation or even decrease in pensions. Hence, our study also has a clear policy implication: amidst tightening budgets in European countries and ballooning pension spending, volunteering can be a viable alternative to support SWB among an increasing population of elderly.

It is especially important given that the burden of aging is increasing-all European countries are aging-and younger generations will have to increasingly pay more for the elderly. 
It is important to highlight that elderly have greater potential to volunteer as they have more time, especially the elderly who are retired. But even those in paid labor, arguably tend to have less harried schedules than younger workers. For instance, elderly could help working age individuals take care of their children, especially given mass labor migration across Europethere is even a new term for children who desperately need care that working age Europeans can barely provide: Euro-orphans (e.g., Nowak et al., 2012).

We also found support for H2a: the higher the income, the less benefit from volunteering in SWB; and for H2b: the higher the wealth, the less benefit from volunteering in SWB. But we did not find support for $\mathrm{H} 2 \mathrm{c}$ : the higher the pensions, the less benefit from volunteering in SWB. Failure of $\mathrm{H} 2 \mathrm{c}$ can be explained, we think, in terms of opportunity cost. Pensions, unlike wealth and especially labor income, are given-one earns them no matter how one spends time. With respect to wealth, and especially labor income, there is clear opportunity cost - the more labor hours, the less volunteering hours. To some degree it is true with respect to wealth, too. For instance, wealth requires management, and wealth can achieve goals of volunteering (e.g., helping others) without an act of volunteering, for instance, one could start a foundation or contribute to one. We acknowledge, however, that there may be other possible explanations for this result. Perhaps, self-selection can explain the results: wealthier or higher income persons may be more individualistic and more aware of their time and schedule constraints, and hence, also less prone to devote time to volunteering. People with higher pensions, on the other hand, may come from the public sector and be more collectivist, social, and devoted to public good and volunteering. Another explanation would be that those who value money less are more eager to be volunteers. This would not be capability to volunteer, but preferences for volunteering. Future research can explore it further.

There is a related issue of retirement age - while people live longer, it is politically difficult to increase retirement age - but this is not economically sustainable. Volunteering can help. For instance, people can still be retiring earlier but if they remain productive through volunteering they can generate free products and services, which would ease budget expenditures and help with deficits. Indeed, in the spirit of nudging as opposed to forcing people (Thaler \& Sunstein, 2008), we suggest such policy: increase retirement age, but allow a person to retire early if she volunteers. ${ }^{8}$

Europe is aging: Fewer babies are born, and Europeans live longer. And healthcare costs are increasing. So people live longer and in better shape, and at the same time retirement age increase is opposed, so there are more untapped resources in terms of labor that elderly could perform. We suggest volunteering - especially in countries with low levels of volunteering, there is a great deal of potential. ${ }^{9}$ For instance, in Western countries many public utility tasks are performed by volunteers such as helping kids cross the street. In the East, on the other hand, these activities are often performed by paid labor that could be used better elsewhere, for instance, in Poland city employees often help children cross the street. In the US, it is often volunteers.

In this study we focused on overall patterns (controlling for country level fixed effects). Future research can explore differences across countries. The goal of this study was to focus on the general relationships and the tradeoff or interplay between pensions (economic capital) and volunteering (social capital).

SHARE are very rich data and there can be much more done in terms of narrowing down and measuring pensions and volunteering. And related concepts can be measured, too. For

\footnotetext{
${ }^{8}$ The devil is in the details, of course-it remains to be worked out how to exactly design and implement such policy.

${ }^{9}$ Our preliminary results (not shown here) suggest that the effect of volunteering on SWB has the strongest potential for growth among countries with low levels of volunteering.
} 
instance, we have found that volunteering works better for poorer persons and suggested that for richer persons giving may contribute more to their SWB. This can be tested using FT001, FT002, FT003, and other FT variables.

Future research could look at the effect of earlier life experiences on successful aging. For instance, Pruchno et al. (2010b, 2010a) found in the US that incarceration, marital, work, and volunteer statuses, as well as moderate alcohol consumption affect successful aging-such approach could be replicated in Europe using SHARELIFE, SHARE's module focused on people's life histories. In particular, it would be interesting to examine effect of earlier volunteering in life on successful aging later - perhaps, not only volunteering later in life, but also earlier has a positive effect.

As any correlational study, causality cannot be established. While panel data does not help much with causality, (an experiment or natural experiment is needed), panel data does help controlling for unobservable heterogeneity if it is time constant.

We did not test for actual substitution, i.e., take away pension and replace with volunteering and SWB remains constant-our results suggest that indeed it may be the case (at least to some degree; again, one needs at least some economic capital that cannot be easily replaced with other capitals). It is a great topic for future research.

Volunteering is not only cheaper but also, as our results indicate, about equally effective in sustaining SWB among elderly. And volunteering is likely to have positive spillover effects. If an elderly volunteers to help another elderly, both are likely to become happier, and perhaps more people may follow the example and volunteer as well. Pensions, on the other hand, may have negative externalities. We know that people compare and income is relative: the more money others have, the more relatively deprived I am (Michalos, 1985, Luttmer, 2005, Bender, 2012). Pensions may have similar negative effects. Indeed, there is anecdotal evidence-we have heard many people speaking of others' pensions with envy, and envy is clearly detrimental to SWB (Mujcic \& Oswald, 2017). In addition, volunteering is a form of social capital or at least is conducive for social capital, and social capital is more conducive for long-term SWB than income (Bartolini \& Sarracino, 2014).

To advance policy making and administration we should ask how much happiness will a policy bring about. ${ }^{10}$ Key advantage of the happiness yardstick is that it overcomes the difficulty of measuring utility in social welfare.

Neighborhood support groups have always played a key role in helping the poor survive (Saegert et al., 2002), and so do individual persons play a key role helping other poor (Mazelis, 2017). Most countries experience rising inequality (Piketty \& Saez, 2003, Mackintosh, 2013, OECD, 2008, Verbeek, 2015) - the middle class is diminishing, ${ }^{11}$ and it is becoming two classes: the rich and the rest. Our results suggest that volunteering may not be the viable strategy for the rich, but it is for the rest.

\section{Acknowledgement}

The project was funded by Narodowe Centrum Nauki (NCN) from "Wpływ transferów społecznych i kapitału społecznego na zadowolenie osób starszych" 2016/21/B/HS4/03058.

${ }^{10}$ Of course, it is not the only metric, neither a perfect one. There are other considerations-notably not everything that makes us happy is the right thing to do. However, if an activity (e.g., volunteering) has other benefits and few if any disadvantages, then SWB yardstick is more appropriate.

${ }^{11}$ For the world as a whole, the inequality is decreasing due to the poor countries, notably China, catching up-in many poor countries, the middle class is actually increasing. 


\section{References}

Aknin, L. B., Barrington-Leigh, C. P., Dunn, E. W., Helliwell, J. F., Burns, J., Biswas-Diener, R., Kemeza, I., Nyende, P., Ashton-James, C. E., \& Norton, M. I. (2013). Prosocial spending and well-being: Cross-cultural evidence for a psychological universal. Journal of Personality and Social Psychology, 104(4), 635.

Alesina, A., Glaeser, E. L., \& Sacerdote, B. (2001). Why doesn't the united states have a european-style welfare state. Brookings Papers on Economic Activity, (2), 187-254.

Alesina, A., Glaeser, E. L., \& Sacerdote, B. (2005). Work and leisure in the u.s. and europe: Why so different? Working Paper 278, National Bureau of Economic Research.

Alvarez-Diaz, A., Gonzalez, L., \& Radcliff, B. (2009). The politics of happiness: On the political determinants of quality of life in the American States. Unpublished Manuscript.

Amit, K. \& Litwin, H. (2010). The subjective well-being of immigrants aged 50 and older in israel. Social indicators research, 98(1), 89-104.

Anderson, N. D., Damianakis, T., Kröger, E., Wagner, L. M., Dawson, D. R., Binns, M. A., Bernstein, S., Caspi, E., \& Cook, S. L. (2014). The benefits associated with volunteering among seniors: a critical review and recommendations for future research. Psychological bulletin, 140(6), 1505.

Angelini, V., Cavapozzi, D., Corazzini, L., \& Paccagnella, O. (2012). Age, health and life satisfaction among older europeans. Social indicators research, 105(2), 293-308.

Ashkanasy, N. M. (2011). International happiness: A multilevel perspective. The Academy of Management Perspectives, 25(1), 23-29.

Bartolini, S. \& Sarracino, F. (2014). Happy for how long? how social capital and economic growth relate to happiness over time. Ecological Economics, 108, 242-256.

Bender, K. A. (2012). An analysis of well-being in retirement: The role of pensions, health, of retirement. The Journal of Socio-Economics, 41(4), 424-433.

Bilan, Y., Mishchuk, H., Samoliuk, N., \& Yurchyk, H. (2020). Impact of income distribution on social and economic well-being of the state. Sustainability, 12(1), 429.

Blanchflower, D. G. \& Oswald, A. J. (2011). International happiness: A new view on the measure of performance. The Academy of Management Perspectives, 25(1), 6-22.

Blom, A. G. \& Schröder, M. (2011). Sample composition 4 years on: retention in share wave 3. Retrospective data collection in the Survey of Health, Ageing and Retirement in Europe, pages 55-61.

Bok, D. (2010). The politics of happiness: What government can learn from the new research on well-being. Princeton University Press, Princeton NJ.

Bonsang, E. \& van Soest, A. (2012). Satisfaction with social contacts of older europeans. Social indicators research, 105(2), 273-292.

Borgonovi, F. (2008). Doing well by doing good. the relationship between formal volunteering and self-reported health and happiness. Social science \& medicine, 66(11), 2321-2334.

Börsch-Supan, A. (2017). Survey of health, ageing and retirement in europe (share) wave 6. Release version: 6.0.0. SHARE-ERIC. Data set: https://doi.org/10.6103/SHARE.w6.600, 6(0).

Butrica, B. A. \& Schaner, S. G. (2005). Satisfaction and engagement in retirement.

Campbell, A., Converse, P. E., \& Rodgers, W. L. (1976). The quality of American life: perceptions, evaluations, and satisfactions. Russell Sage Foundation, New York NY.

Cannas, M., Sergi, B. S., Sironi, E., \& Mentel, U. (2019). Job satisfaction and subjective wellbeing in europe. Economics \& Sociology, 12(4), 183-332.

De Tocqueville, A. (2003). Democracy in America, volume 10. Gateway Editions. 
Di Tella, R. \& MacCulloch, R. (2006). Some uses of happiness data in economics. The Journal of Economic Perspectives, 20(1), 25-46.

Di Tella, R., MacCulloch, R. J., \& Oswald, A. J. (2001a). The macroeconomics of happiness. Warwick Economic Research Papers No 615.

Di Tella, R., MacCulloch, R. J., \& Oswald, A. J. (2001b). Preferences over inflation and unemployment: Evidence from surveys of happiness. American Economic Review, 91(1), $335-341$.

Diener, E. (2009). Well-being for public policy. Oxford University Press, New York NY.

Diener, E. \& Seligman, M. E. P. (2004). Beyond money: Toward an economy of well-being. Psychological Science, 5(1), 1-31.

Dingemans, E. \& Henkens, K. (2014). Involuntary retirement, bridge employment, and satisfaction with life: A longitudinal investigation. Journal of Organizational Behavior, 35(4), 575-591.

Dingemans, E. \& Henkens, K. (2015). How do retirement dynamics influence mental wellbeing in later life? a 10-year panel study. Scand J Work Environ Health, 41(1), 16-23.

Dolan, P., Peasgood, T., \& White, M. (2008). Do we really know what makes us happy a review of the economic literature on the factors associated with subjective well-being. Journal of Economic Psychology, 29(1), 94-122.

D'Silva, J. L. \& Samah, A. A. (2018). Holistic well-being of japanese retirees in malaysia. Journal of International Studies, 11(3).

Dulin, P. L., Gavala, J., Stephens, C., Kostick, M., \& McDonald, J. (2012). Volunteering predicts happiness among older māori and non-māori in the new zealand health, work, and retirement longitudinal study. Aging \& mental health, 16(5), 617-624.

Easterlin, R. A., McVey, L. A., Switek, M., Sawangfa, O., \& Zweig, J. S. (2010). The happiness-income paradox revisited. Proceedings of the National Academy of Sciences, 107(52), 22463-22468.

Ferrer-i-Carbonell, A. \& Frijters, P. (2004). How important is methodology for the estimates of the determinants of happiness? Economic Journal, 114(497), 641-659.

Ferring, D. \& Boll, T. (2010). Subjective wellbeing in older adults: Current state and gaps of research. In Lans Bovenberg, Arthur van Soest, A. Z., editor, Ageing, health and pensions in Europe, pages 173-212. Springer.

Fischer, C. S. (2010). Made in America: A social history of American culture and character. University of Chicago Press, Chicago IL.

Frijters, P., Haisken-Denew, J. P., \& Shields, M. a. (2004). Money does matter! evidence from increasing real income and life satisfaction in east germany following reunification. American Economic Review, 94(3), 730-740.

Gujarati, D. N. (2002). Basic Econometrics. Mcgraw-Hill, New York.

Gwozdz, W. \& Sousa-Poza, A. (2010). Ageing, health and life satisfaction of the oldest old: An analysis for germany. Social Indicators Research, 97(3), 397-417.

Hank, K. \& Erlinghagen, M. (2009). Dynamics of volunteering in older europeans. The Gerontologist, 50(2), 170-178.

Haski-Leventhal, D. (2009). Elderly volunteering and well-being: A cross-european comparison based on share data. Voluntas: International Journal of Voluntary and Nonprofit Organizations, 20(4), 388-404.

Hyde, M., Higgs, P., Wiggins, R., \& Blane, D. (2015). A decade of research using the casp scale: key findings and future directions.

Hyde, M., Wiggins, R. D., Higgs, P., \& Blane, D. B. (2003a). A measure of quality of life in early old age: the theory, development and properties of a needs satisfaction model (casp19). Aging \& mental health, 7(3), 186-194. 
Hyde, M., Wiggins, R. D., Higgs, P., \& Blane, D. B. (2003b). A measure of quality of life in early old age: the theory, development and properties of a needs satisfaction model (casp19). Aging \& mental health, 7(3), 186-194.

Jenkinson, C. E., Dickens, A. P., Jones, K., Thompson-Coon, J., Taylor, R. S., Rogers, M., Bambra, C. L., Lang, I., \& Richards, S. H. (2013). Is volunteering a public health intervention? a systematic review and meta-analysis of the health and survival of volunteers. BMC public health, 13(1), 773.

Jürges, H. \& van Soest, A. (2012). Comparing the well-being of older europeans: Introduction. Social indicators research, 105(2), 187-190.

Kahneman, D. \& Deaton, A. (2010). High income improves evaluation of life but not emotional well-being. Proceedings of the National Academy of Sciences, 107(38), 16489-16493.

Kahneman, D., Diener, E., \& Schwarz, N. (1999). Well-being: Foundations of hedonic psychology. Russell Sage Foundation.

Kim, G. R., Netuveli, G., Blane, D., Peasey, A., Malyutina, S., Simonova, G., Kubinova, R., Pajak, A., Croezen, S., Bobak, M., et al. (2015). Psychometric properties and confirmatory factor analysis of the casp-19, a measure of quality of life in early old age: the hapiee study. Aging \& mental health, 19(7), 595-609.

Klein, K. J. \& Kozlowski, S. W. (2000). From micro to meso: Critical steps in conceptualizing and conducting multilevel research. Organizational Research Methods, 3(3), 211-236.

Knesbeck, O., Hyde, M., Higgs, P., Kurlan, R., \& Siegrist, J. (2005). Quality of life and wellbeing.

Kushlev, K., Dunn, E. W., \& Lucas, R. E. (2015). Higher income is associated with less daily sadness but not more daily happiness. Social Psychological and Personality Science, 6(5), 483-489.

Layard, R. (2005). Happiness. Lessons from a new science. The Penguin Press, New York NY.

Lipset, S. M. \& Marks, G. (2000). It didn't happen here: why socialism failed in the United States. WW Norton \& Company, New York NY.

Luttmer, E. F. P. (2005). Neighbors as negatives: Relative earnings and well-being. Quarterly Journal of Economics, 120(3), 963-02.

Mackintosh, E. (2013). Report: Income inequality rising in most developed countries. Washington Post.

Maslow, A. ([1954] 1987). Motivation and personality. Longman, 3 edition.

Mazelis, J. M. (2017). Surviving Poverty: Creating Sustainable Ties Among the Poor. NYU Press.

McMahon, D. M. (2005). The quest for happiness. Wilson Quarterly, 29(1), 62-71.

McMahon, D. M. (2006). Happiness: A history. Grove Pr.

Meier, S. \& Stutzer, A. (2008a). Is volunteering rewarding in itself? Economica, 75(297), 3959.

Meier, S. \& Stutzer, A. (2008b). Is volunteering rewarding in itself? Economica, 75(297), 3959.

Michalos, A. (1985). Multiple discrepancies theory (mdt). Social Indicators Research, 16(4), $347-413$.

Morrison, P. S. \& Weckroth, M. (2017). Human values, subjective well-being and the metropolitan region. Regional Studies, pages 1-13.

Mujcic, R. \& Oswald, A. J. (2017). Is envy harmful to a society's psychological health and wellbeing? a longitudinal study of 18,000 adults. Social Science \& Medicine.

Myers, D. G. (2000). The funds, friends, and faith of happy people. American Psychologist, 55(1), 56-67. 
Nikolova, M. \& Graham, C. (2014). Employment, late-life work, retirement, and well-being in europe and the united states. IZA Journal of European Labor Studies, 3(1), 1-30.

Nowak, M., Gaweda, A., \& Janas-Kozik, M. (2012). The euro-orphans phenomenon and the courses in therapeutic work and psychiatric treatment-a case study. Psychiatria polska, 46(2), 295-304.

OCDE (2013). Pensions at a glance 2013. oecd and g20 indicators.

OECD (2008). Income inequality and poverty rising in most oecd countries. OECD Press Release:

http://www.oecd.org/general/incomeinequalityandpovertyrisinginmostoecdcountries.ht $\mathrm{m}$.

Okulicz-Kozaryn, A. (2013). City life: Rankings (livability) versus perceptions (satisfaction). Social Indicators Research, 110(2), 433-451.

Okulicz-Kozaryn, A. (2016). Happiness research for public policy and administration. Transforming Government: People, Process and Policy.

Okulicz-Kozaryn, A., Holmes IV, O., \& Avery, D. R. (2014). The subjective well-being political paradox: Happy welfare states and unhappy liberals. Journal of Applied Psychology, 99(6), 1300-1308.

Okulicz-Kozaryn, A. \& Mazelis, J. M. (2016). More unequal in income, more unequal in wellbeing. Social Indicators Research.

Okulicz-Kozaryn, A. \& Valente, R. R. (2019). Livability and subjective well-being across european cities. Applied Research in Quality of Life, 14(1), 197-220.

Oswald, A. (2014). Keynote ii. 2014 Wellbeing and Public Policy Conference at Hamilton College.

Pacek, A. \& Radcliff, B. (2008a). Assessing the welfare state: The politics of happiness. Perspectives on Politics, 6(2), 267-277.

Pacek, A. \& Radcliff, B. (2008b). Welfare policy and subjective well-being across nations: An individual-level assessment. Social Indicators Research, 89(1), 179 - 191.

Pérez-Rojo, G., Martín, N., Noriega, C., \& López, J. (2017). Psychometric properties of the casp-12 in a spanish older community dwelling sample. Aging \& mental health, pages $1-$ 9.

Piketty, T. \& Saez, E. (2003). Income inequality in the united states, 1913-1998. The Quarterly Journal of Economics, 118(1), 1-41.

Proctor, J. (2006). Religion as trust in authority: Theocracy and ecology in the united states. Annals of the Association of American Geographers, 96(1), 188-196.

Pruchno, R. A., Wilson-Genderson, M., \& Cartwright, F. (2010a). A two-factor model of successful aging. Journals of Gerontology Series B: Psychological Sciences and Social Sciences, 65(6), 671-679.

Pruchno, R. A., Wilson-Genderson, M., Rose, M., \& Cartwright, F. (2010b). Successful aging: Early influences and contemporary characteristics. The Gerontologist, 50(6), 821-833.

Radcliff, B. (2001). Politics, markets, and life satisfaction: The political economy of human happiness. American Political Science Review, 95(4), 939-952.

Radcliff, B. (2013). The Political Economy of Human Happiness: How Voters' Choices Determine the Quality of Life. Cambridge University Press, New York NY.

Ryan, R. M., Chirkov, V. I., Little, T. D., Sheldon, K. M., Timoshina, E., \& Deci, E. L. (1999). The american dream in russia: Extrinsic aspirations and well-being in two cultures. Personality and social psychology bulletin, 25(12), 1509-1524.

Saegert, S., Thompson, J. P., \& Warren, M. R. (2002). Social capital and poor communities. Russell Sage Foundation. 
Schmuck, P., Kasser, T., \& Ryan, R. M. (2000). Intrinsic and extrinsic goals: Their structure and relationship to well-being in german and us college students. Social Indicators Research, 50(2), 225-241.

Scruggs, L. \& Allan, J. (2006). Welfare-state decommodification in 18 oecd countries: A replication and revision. Journal of European Social Policy, 16(1), 55-72.

Senlier, N., Yildiz, R., \& Akta, E. (2009). A perception survey for the evaluation of urban quality of life in kocaeli and a comparison of the life satisfaction with the european cities. Social Indicators Research, 94, 213-226.

Stolnitz, G. J. (1992). Demographic causes and economic consequences of population aging: Europe and north america.

Thaler, R. \& Sunstein, C. (2008). Nudge: Improving decisions about health, wealth, and happiness. Yale University Press.

Van Willigen, M. (2000). Differential benefits of volunteering across the life course. The Journals of Gerontology Series B: Psychological Sciences and Social Sciences, 55(5), S308-S318.

Vanhoutte, B. (2012). Measuring subjective well-being: a review. CCSR Woking Paper.

Vanhoutte, B. (2014). The multidimensional structure of subjective well-being in later life. Journal of population ageing, 7(1), 1-20.

Vaupel, J. W. \& Loichinger, E. (2006). Redistributing work in aging europe. Science, 312(5782), 1911-1913.

Veenhoven, R. (2008). Sociological theories of subjective well-being. In Eid, M. and Larsen, R., editors, The Science of Subjective Well-being: A tribute to Ed Diener, pages 44-61. The Guilford Press, New York NY.

Veenhoven, R. (2012). Evidence-based pursuit of happiness: What we should know, what we do know and what we can get to know. Technical report, EHERO.

Verbeek, J. (2015). Increasingly, inequality within, not across, countries is rising. The World bank Development Talk http://blogs.worldbank.org/developmenttalk/increasinglyinequality-within-not-across-countries-rising.

Vidlund, M. \& Bach-Othman, J. (2009). Pension contribution level in nine european countries. Finnish Centre for Pensions, Working Papers 2009, 1.

Wahrendorf, M., von dem Knesebeck, O., \& Siegrist, J. (2006). Social productivity and wellbeing of older people: baseline results from the share study. European Journal of Ageing, $3(2), 67-73$.

Wheeler, J. A., Gorey, K. M., \& Greenblatt, B. (1998). The beneficial effects of volunteering for older volunteers and the people they serve: A meta-analysis. The International Journal of Aging and Human Development, 47(1), 69-79.

Wilson, E. O. (2012a). On human nature. Harvard University Press.

Wilson, J. (2012b). Volunteerism research: A review essay. Nonprofit and Voluntary Sector Quarterly, 41(2), 176-212.

Wiwad, D. \& Aknin, L. B. (2017). Motives matter: The emotional consequences of recalled self-and other-focused prosocial acts. Motivation and Emotion, 41(6), 730-740. 


\section{Appendix}

\section{Descriptive statistics}

Table 5. Variable definitions: dependent variables

\begin{tabular}{ll}
\hline \multicolumn{1}{c}{ Name } & \multicolumn{1}{c}{ Description } \\
\hline life satisfaction & $\begin{array}{l}\text { "On a scale from 0 to 10 where 0 means completely dissatisfied and 10 means } \\
\text { completely satisfied, how satisfied are you with your life?" [imputed] }\end{array}$ \\
\hline casp & casp scale: see table 1 [ac]
\end{tabular}

Source: own compilation

[imputed], [ac], and [ep] pertain to SHARE modules.

Table 6. Variable definitions: social activities

\begin{tabular}{|c|c|}
\hline Name & \\
\hline $\begin{array}{l}\text { voluntary or charity } \\
\text { work }\end{array}$ & $\begin{array}{l}\text { "Please look at card 38: which of the activities listed on this card - if any - } \\
\text { have you done in the past twelve months?" [ac] }\end{array}$ \\
\hline \multicolumn{2}{|c|}{$\begin{array}{l}\text { how often done voluntary"How often in the past twelve months did you [do voluntary or charity work]?" } \\
\text { or charity work } \quad \text { [ac] }\end{array}$} \\
\hline $\begin{array}{l}\text { ttended an educational } \\
\mathrm{r} \text { training course }\end{array}$ & $\begin{array}{l}\text { "Plea } \\
\text { have }\end{array}$ \\
\hline cial or & $\begin{array}{l}\text { "Plea } \\
\text { have }\end{array}$ \\
\hline \multicolumn{2}{|c|}{$\begin{array}{l}\text { taken part in a political or"Please look at card 38: which of the activities listed on this card - if any - } \\
\text { community-related } \\
\text { organization }\end{array}$} \\
\hline $\mathrm{ad}$ & $\begin{array}{l}\text { r"Plea } \\
\text { have }\end{array}$ \\
\hline $\begin{array}{l}\text { did word or number } \\
\text { games (crossword }\end{array}$ & ard - if any - \\
\hline $\begin{array}{l}\text { layed cards or game } \\
\text { uch as chess }\end{array}$ & \\
\hline
\end{tabular}

Source: own compilation

[imputed], [ac], and [ep] pertain to SHARE modules. 
Table 7. Variable definitions: social transfers

\begin{tabular}{cc}
\hline Name & Description \\
\hline annual old age early & EP078 1-2-3-7-8-9 (1-2-3-9-10-11 in 6 "After taxes, about how large was
\end{tabular}

annual old age, early EP078_1-2-3-7-8-9 (1-2-3-9-10-11 in w6) "After taxes, about how large was retirement pensions, a typical payment of [ your public old age pension/ your public old age survivor and war pension supplementary pension or public old age second pension/ your public early PPP '000 retirement or pre-retirement pension/ your main public sickness benefits/ your main public disability insurance pension/ your secondary public disability insurance pension/ your Secondary public sickness benefits/ your public unemployment benefit or insurance/ your main public survivor pension from your spouse or partner/ your secondary public survivor pension from your spouse or partner/ your public war pension/ your public long-term care insurance/ your social assistance] in [STR (Year - 1)]?" [imputed]

annual private "After taxes, what was the approximate annual amount received from all your occupational pensions PPP '000 occupational pensions in [STR (Year - 1)]?" [imputed]

other regular payments from private pernsions PPP '000

"After any taxes and contributions, about how large was the average payment of [ you life insurance payments from a private insurance company/ your private annuity or private personal pension payments/ your alimony/ your regular payments from charities/ your long-term care insurance payments] in [STR (Year - 1)]?" [imputed]

pension PPP '000 EP078_1-2-3-7-8-9 (1-2-3-9-10-11 in w6) from annual old age, early retirement pensions, survivor and war pension AND from annual private occupational pensions AND other regular payments from private pernsions [imputed]

disability/sickness EP078_5-6 and EP078_3_6_10 (4-7 in w6) [from question in "annual old age, benefits PPP '000 early retirement pensions, survivor and war pension"] [imputed]

unemployment benefits EP078_6 (8 in w6) [from question in "annual old age, early retirement PPP '000 pensions, survivor and war pension"] [imputed]

social assistance PPP EP078_10 (12-13 in w6) [from question in "annual old age, early retirement '000 pensions, survivor and war pension"] [imputed]

Source: own compilation

[imputed], [ac], and [ep] pertain to SHARE modules. 
Table 8. Variable definitions: control variables

\begin{tabular}{|c|c|}
\hline Name & Description \\
\hline labor income PPP ’000 & $\begin{array}{l}\text { "After any taxes and contributions, what was your approximate annual income } \\
\text { from employment in the year [STR (Year - 1)]? Please include any additional } \\
\text { or extra or lump sum payment, such as bonuses, } 13 \text { month, Christmas or } \\
\text { Summer pays." AND "After any taxes and contributions and after paying for } \\
\text { any materials, equipment or goods that you use in your work, what was your } \\
\text { approximate annual income from self-employment in the year [STR (Year - } \\
\text { 1)]?" [imputed] }\end{array}$ \\
\hline \multicolumn{2}{|c|}{$\begin{array}{l}\text { household net worth PPP calculated variable-see Release Guide 6.0.0 [imputed] } \\
\text { ’000 }\end{array}$} \\
\hline years of education & $\begin{array}{l}\text { "How many years have you been in full-time education?" full-time education } \\
\text { * includes: receiving tuition, engaging in practical work or supervised study } \\
\text { or taking examinations * excludes: full-time working, home schooling, } \\
\text { distance learning, special on-the-job training, evening classes, part-time } \\
\text { private vocational training, flexible or part-time higher education studies, etc } \\
\text { [imputed] }\end{array}$ \\
\hline age & $\begin{array}{l}\text { Age of respondent (based on interview year) "In which month and @byear@b } \\
\text { were you born?" [imputed] }\end{array}$ \\
\hline male & OBSERVATION Note sex of respondent from observation (ask if unsure) \\
\hline self reported health & "Would you say your health is..." "Poor"..."Excellent" [imputed] \\
\hline $\begin{array}{l}\text { permanently sick or } \\
\text { disabled }\end{array}$ & $\begin{array}{l}\text { "Please look at card 7. In general, which of the following best describes your } \\
\text { @ bcurrent@ } @ \text { b employment situation?" "1. Retired; } 2 \text {. Employed or self- } \\
\text { employed (including working for family business); 3. Unemployed; } 4 . \\
\text { Permanently sick or disabled; 5. Homemaker; 97. Other" coded } 1 \text { if } \\
\text { "Permanently sick or disabled"; } 0 \text { otherwise [EP] }\end{array}$ \\
\hline mobility limitations & $\begin{array}{l}\text { "Please tell me whether you have any difficulty doing each of the everyday } \\
\text { activities on this card. Exclude any difficulties that you expect to last less than } \\
\text { three months. } 1 \text {. Walking } 100 \text { metres; } 2 \text {. Sitting for about two hours; } 3 \text {. Getting } \\
\text { up from a chair after sitting for long periods; } 4 \text {. Climbing several flights of } \\
\text { stairs without resting; } 5 \text {. Climbing one flight of stairs without resting; } 6 \text {. } \\
\text { Stooping, kneeling, or crouching; } 7 \text {. Reaching or extending your arms above } \\
\text { shoulder level; } 8 \text {. Pulling or pushing large objects like a living room chair; } 9 \text {. } \\
\text { Lifting or carrying weights over } 10 \text { pounds } / 5 \text { kilos, like a heavy bag of } \\
\text { groceries; } 10 \text {. Picking up a small coin from a table" [imputed] }\end{array}$ \\
\hline $\begin{array}{l}\text { married and living } \\
\text { together }\end{array}$ & "What is your marital status?" [imputed] \\
\hline employed & $\begin{array}{l}\text { The following questions are about your current main job. "In this job were you } \\
\text { a private-sector employee, a public sector employee or self-employed?" } \\
\text { [imputed] }\end{array}$ \\
\hline nl & $\begin{array}{l}\text { "Talking about grandchildren, how many grandchildren do you [ and your/ } \\
\text { and your/ and your/ and your] [husband/ wife/ partner/ partner] have } \\
\text { altogether?" [imputed] }\end{array}$ \\
\hline
\end{tabular}

Source: own compilation

[imputed], [ac], and [ep] pertain to SHARE modules.

Household Net Worth (hetw): sum of hnfass (household financial assets) and hrass (household real assets). Hnfass: money on bank accounts plus money in bonds, stocks and mutual funds plus savings for long-term investments minus any financial liabilities. Hrass: (value of main residence times percentage of house owned divided by 100) plus (value of own business times share of own business divided by 100) plus value of cars plus value of other real estate minus mortgages." 
Please note per histograms below: Because we mostly use imputed dataset some values are not integers even when base question does not include fraction such as dummy variable for being married.
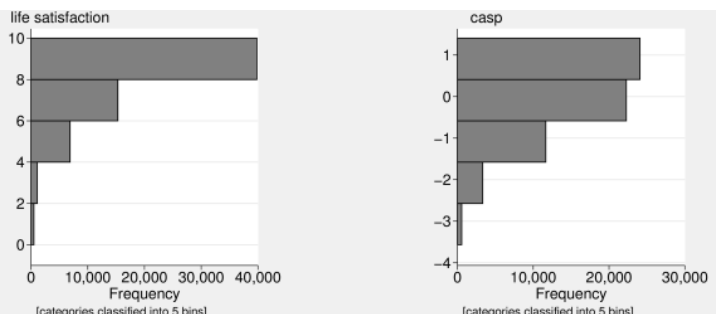

Figure 2. Variables' distribution

Source: own compilation
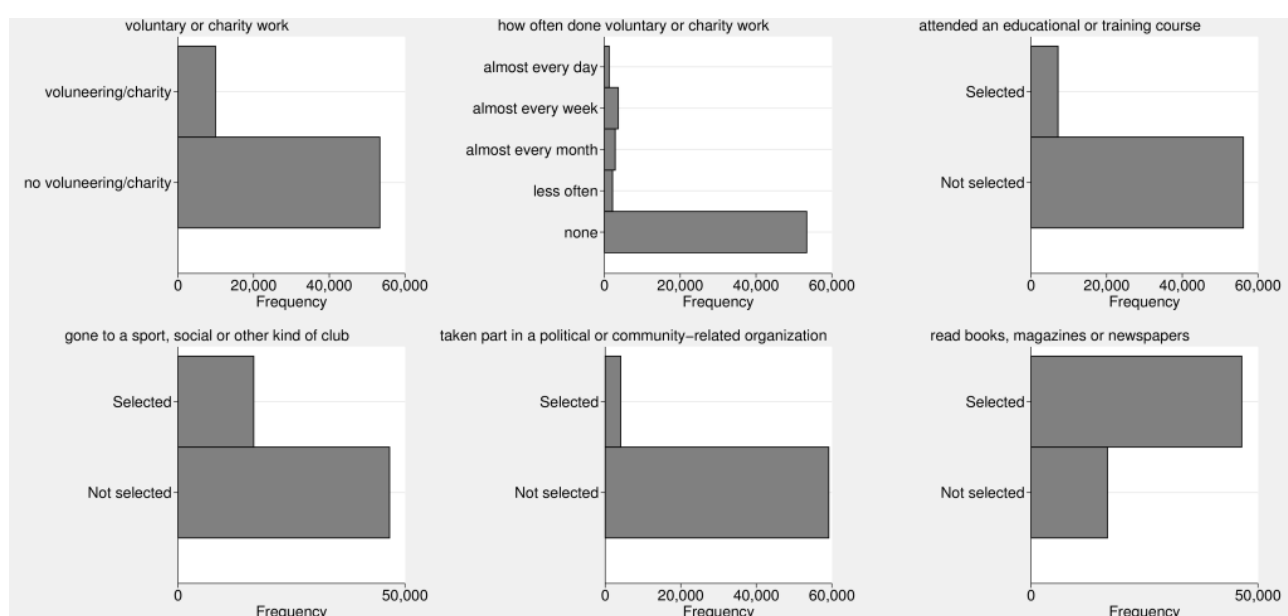

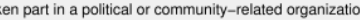

read books, magazines or newspapers
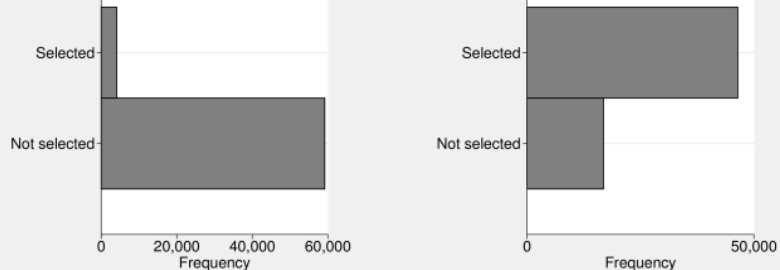

did word or number games (crossword puzzles/Sudoku...)

played cards or games such as chess
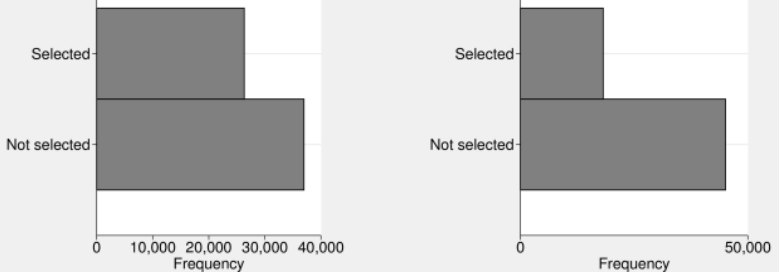

Figure 3. Variables' distribution

Source: own compilation 


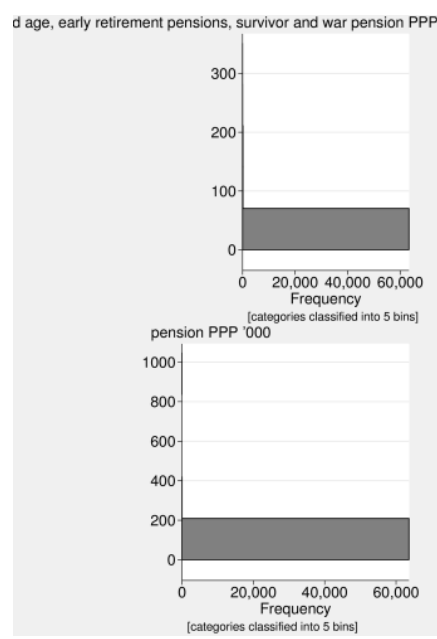

Figure 4. Variables' distribution

Source: own compilation
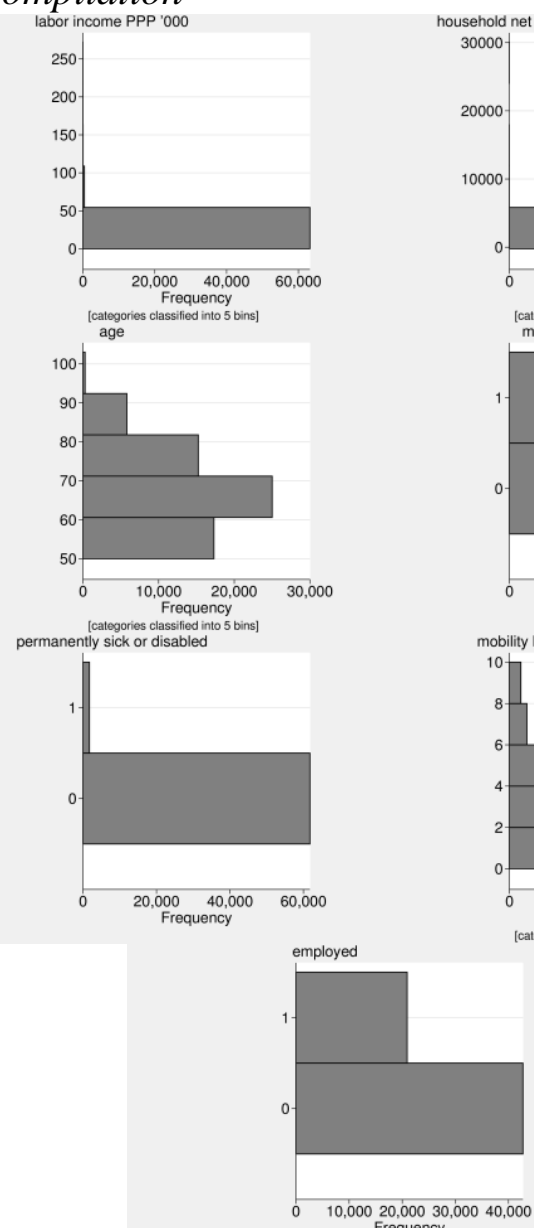

Figure 5. Variables' distribution

Source: own compilation
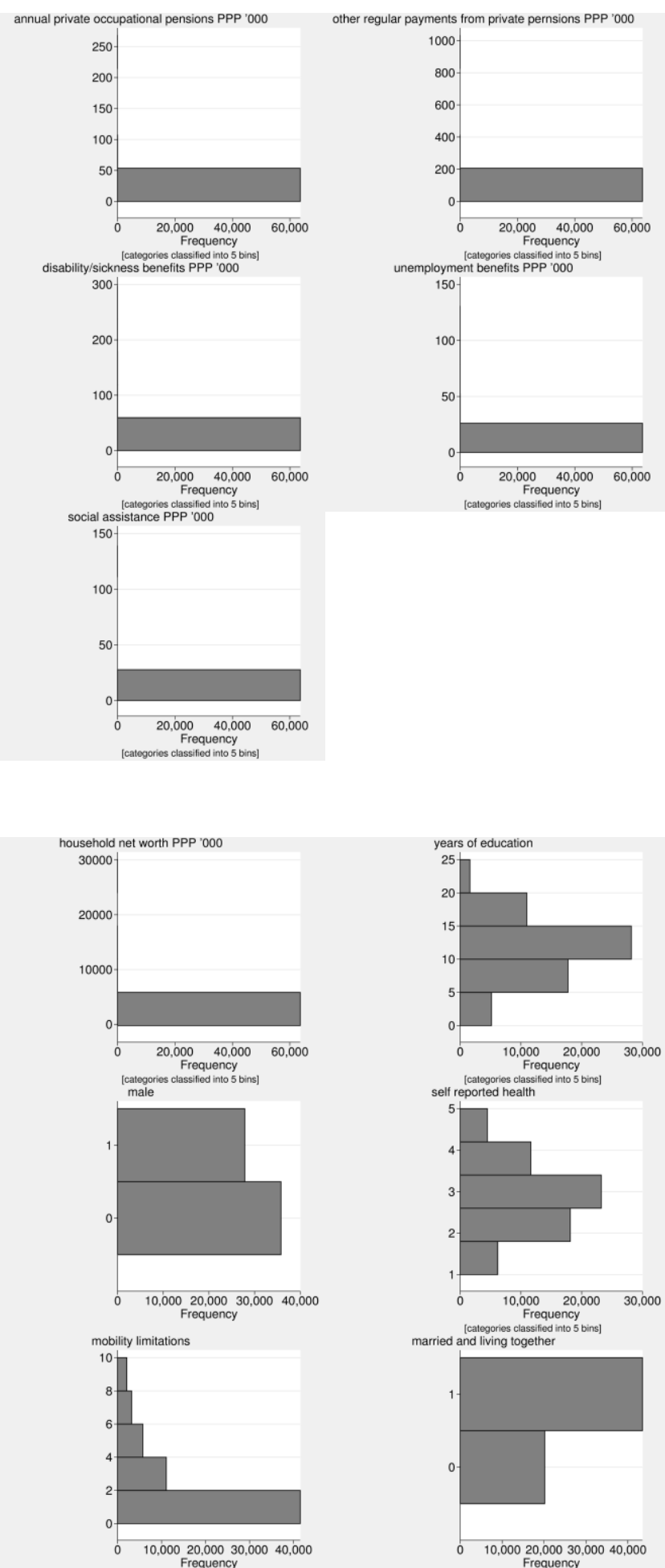
Frequency Frequency
[calegories classified into 5 bind

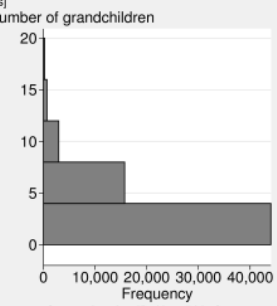




\section{Appendix}

\section{Baseline regression results}

We start with "traditional" ways of increasing one's wellbeing: income, wealth, and social transfers in table 9; then we turn to volunteering and other forms of social capital.

A typical way to support oneself before retirement is labor income. We start with this basic relationship in column a1. Among elderly, typical way to support oneself is pensionadded in a2-both income and pension have substantial and statistically significant effect on SWB. Other types of replacement income include unemployment, social assistance, and disability/sickness benefits-added in a3. They all predict lower SWB-this is not unexpectedthey not only add income but also proxy a considerable misfortune, otherwise one would not be eligible for them. Correlations among these different types of social transfers are low, below .1. About two thirds of our sample of about $65 \mathrm{k}$ receive pensions, only about $1.2 \mathrm{k}$ receive unemployment benefits, about $1 \mathrm{k}$ receive social assistance, and about $4.5 \mathrm{k}$ receive disability/sickness benefits. We have also tried modeling nonlinear effects of pensions, labor income, and household net worth, but we did not find much of a curvilinear relationship-the line curves at high values, outside of typical range of data. In general, the more money, the higher the SWB among European elderly.

Finally, column a4 adds other predictors of SWB as controls and the effect of labor income drops by about half and is as large as that of pension in this fullest specification. Column a4 also adds household net worth, and as expected, it attenuates effect of labor income and pension-one needs less of them if one has a stock of wealth.

Columns a4-a8 repeat exercise but now with CASP as a dependent variable-estimates are similar, except that they are stronger. This is expected. Again, CASP was specifically designed to measure wellbeing of elderly. Estimates on controls are mostly as expected with health being the key factor. The effect of age may seem surprising-it is positive-but in fact SWB mostly increases with age and only at the very end it drops (Gwozdz and Sousa-Poza 2010), and this is also what we find: is negative. 
Table 9. OLS of SWB (life satisfaction and CASP) on pensions and other transfers including income and wealth. Beta (fully standardized) coefficients reported. All models include country dummies

\begin{tabular}{|c|c|c|c|c|c|c|c|c|}
\hline & $\begin{array}{c}\text { Life } \\
\text { satisfaction }\end{array}$ & & & & CASP & & & \\
\hline & a1 & a2 & a3 & $\mathrm{a} 4$ & a5 & a6 & a7 & a8 \\
\hline labor income PPP '000 & $0.08 * * *$ & $0.10 * * *$ & $0.07 * * *$ & $0.04 * * *$ & $0.18 * * *$ & $0.19 * * *$ & $0.16 * * *$ & $0.04 * * *$ \\
\hline pension PPP '000 & & $0.07 * *$ & $0.06 * *$ & $0.03 * *$ & & $0.06 * *$ & $0.04 * *$ & $0.04 * *$ \\
\hline $\begin{array}{l}\text { unemployment benefits PPP } \\
{ }^{0} 000\end{array}$ & & & $-0.03 *$ & -0.02 & & & -0.01 & -0.01 \\
\hline social assistance PPP '000 & & & $-0.04 * * *$ & 0.00 & & & $-0.06 * * *$ & -0.01 \\
\hline $\begin{array}{l}\text { disability/sickness benefits PPP } \\
{ }^{0} 00\end{array}$ & & & $-0.05 * * *$ & -0.00 & & & $-0.04 * * *$ & 0.01 \\
\hline household net worth PPP '000 & & & $0.11 * * *$ & $0.05 * * *$ & & & $0.13 * * *$ & $0.05 * * *$ \\
\hline male & & & & $-0.02 * *$ & & & & -0.01 \\
\hline married and living together & & & & $0.15 * * *$ & & & & $0.08 * * *$ \\
\hline employed & & & & $0.02+$ & & & & $0.04 * * *$ \\
\hline age & & & & $0.45 * *$ & & & & $0.99 * * *$ \\
\hline age 2 & & & & $-0.29 *$ & & & & $-0.96 * * *$ \\
\hline years of education & & & & $0.02 * *$ & & & & $0.07 * * *$ \\
\hline number of grandchildren & & & & 0.01 & & & & $0.02 *$ \\
\hline permanently sick or disabled & & & & $-0.04 *$ & & & & $-0.03 *$ \\
\hline mobility limitations & & & & $-0.13 * * *$ & & & & $-0.23 * * *$ \\
\hline self reported health & & & & $0.26 * * *$ & & & & $0.31 * * *$ \\
\hline constant & $* * *$ & $* * *$ & $* * *$ & $* * *$ & $* * *$ & $* * *$ & $* * *$ & $* * *$ \\
\hline $\mathrm{N}$ & 63299 & 63299 & 63299 & 63198 & 61590 & 61590 & 61590 & 61502 \\
\hline $\begin{array}{l}+\mathrm{p}<0.10 * \mathrm{p}<0.05 \quad * * \mathrm{p}<0.01 \\
* * * \mathrm{p}<0.001, \text { robust std err }\end{array}$ & & & & & & & & \\
\hline
\end{tabular}

Source: own compilation

In sum, as expected, both labor income and replacement income in form of pension have significant and considerable effect on SWB. Hence, increasing pensions, could lead to increased SWB. But from public policy standpoint such solution is not sustainable-European budgets are already in red, and societies are aging. Can we increase wellbeing in other ways than using social transfers? We turn to social capital in table 10.

We start with volunteering only in b1. The base case is "no volunteering." "Volunteering only almost every month" already affects SWB significantly. There is not much further increase for "almost every week," and then the positive effect actually decreases for "almost every day." This pattern persists when adding more controls. B2 adds other forms of social capital, and their addition cuts the effect of volunteering by half. Interestingly, least social activity, "read books, magazines or newspapers" has the largest effect on SWB. The second largest effect is from "sport, social or other club" and a large effect is expected-social engagement is key for SWB. Tetrachoric correlations among activities are low to moderate, ranging between .1 and .5 except "read books, magazines or newspapers" is correlated with "did word or number games (crossword puzzles/Sudoku...)" at .6.

B3 adds controls for employment-an important factor to consider when volunteeringbecause those who are employed have less time and higher opportunity cost of volunteering. Surprisingly, estimates on volunteering remain unchanged. We will return to employment in the next section. Addition of usual controls in b4 attenuates the effect of volunteering. 
Table 10. OLS of SWB (life satisfaction and CASP) on volunteering and other social capital. Beta (fully standardized) coefficients reported. All models include country dummies

\begin{tabular}{|c|c|c|c|c|c|c|c|c|}
\hline & $\begin{array}{c}\text { Life } \\
\text { atisfaction }\end{array}$ & & & & CASP & & & \\
\hline & b1 & $\mathrm{b} 2$ & b3 & b4 & b5 & b6 & b7 & b8 \\
\hline \multicolumn{9}{|l|}{ voluntary or charity work: } \\
\hline -less often & 0.01 & -0.00 & -0.00 & -0.01 & $0.05 * * *$ & $0.02 *$ & $0.02 *$ & 0.01 \\
\hline -almost every month & $0.04 * * *$ & $0.02 * * *$ & $0.02 * *$ & 0.01 & $0.08 * * *$ & $0.05 * * *$ & $0.05 * * *$ & $0.03 * * *$ \\
\hline -almost every week & $0.06 * * *$ & $0.03 * * *$ & $0.03 * * *$ & $0.01 *$ & $0.09 * * *$ & $0.05 * * *$ & $0.05 * * *$ & $0.03 * * *$ \\
\hline -almost every day & $0.04 * * *$ & $0.02 * *$ & $0.02 * *$ & $0.02 *$ & $0.07 * * *$ & $0.04 * * *$ & $0.04 * * *$ & $0.03 * * *$ \\
\hline $\begin{array}{l}\text { attended an educational or } \\
\text { training course }\end{array}$ & & $0.03 * * *$ & $0.02 *$ & 0.01 & & $0.08 * * *$ & $0.04 * * *$ & $0.02 * * *$ \\
\hline $\begin{array}{l}\text { gone to a sport, social or other } \\
\text { kind of club }\end{array}$ & & $0.09 * * *$ & $0.08 * * *$ & $0.04 * * *$ & & $0.12 * * *$ & $0.11 * * *$ & $0.05 * * *$ \\
\hline $\begin{array}{l}\text { taken part in a political or } \\
\text { community-related } \\
\text { organization }\end{array}$ & & 0.01 & 0.00 & -0.00 & & $0.03 * * *$ & $0.02 * * *$ & $0.01 *$ \\
\hline $\begin{array}{l}\text { read books, magazines or } \\
\text { newspapers }\end{array}$ & & $0.11 * * *$ & $0.11 * * *$ & $0.07 * * *$ & & $0.16 * * *$ & $0.15 * * *$ & $0.10 * * *$ \\
\hline $\begin{array}{l}\text { did word or number games } \\
\text { (crossword puzzles, Sudoku...) }\end{array}$ & & $0.02+$ & $0.02 *$ & 0.01 & & $0.03 * * *$ & $0.04 * * *$ & $0.03 * * *$ \\
\hline $\begin{array}{l}\text { played cards or games such as } \\
\text { chess }\end{array}$ & & $0.03 * * *$ & $0.03 * * *$ & $0.02 * *$ & & $0.04 * * *$ & $0.04 * * *$ & $0.03 * * *$ \\
\hline employed & & & $0.05 * * *$ & $0.04 * *$ & & & $0.17 * * *$ & $0.05 * * *$ \\
\hline$\underline{\text { male }}$ & & & & -0.01 & & & & $0.01 *$ \\
\hline married and living together & & & & $0.15 * * *$ & & & & $0.08 * * *$ \\
\hline age & & & & $0.40 * *$ & & & & $0.89 * * *$ \\
\hline age 2 & & & & $-0.23+$ & & & & $-0.85 * * *$ \\
\hline years of education & & & & 0.01 & & & & $0.04 * * *$ \\
\hline number of grandchildren & & & & 0.01 & & & & $0.02 * *$ \\
\hline permanently sick or disabled & & & & $-0.04 *$ & & & & $-0.03 * *$ \\
\hline mobility limitations & & & & $-0.13 * * *$ & & & & $-0.23 * * *$ \\
\hline self reported health & & & & $0.26 * * *$ & & & & $0.30 * * *$ \\
\hline $\mathrm{N}$ & 62959 & 62959 & 62959 & 62959 & 61487 & 61487 & 61487 & 61487 \\
\hline
\end{tabular}

$+\mathrm{p}<0.10 \quad * \mathrm{p}<0.05 \quad * * \mathrm{p}<0.01$

$* * * \mathrm{p}<0.001$, robust std err

Source: own compilation 


\section{Appendix}

\section{Additional results}

Comparison of effect sizes of social transfers from table 9 with forms of social capital from table 10 reveals that pension (and labor income) are stronger predictors of SWB, even by about two-fold, than forms of social capital, notably volunteering.

Likewise, results in table 11 show that elders who are retired derive more wellbeing from volunteering. This makes sense-they have more time and lower opportunity cost.

Table 11. OLS of SWB (life satisfaction and CASP) on volunteering and pensions. Unstandardized coefficients reported. All models include country dummies

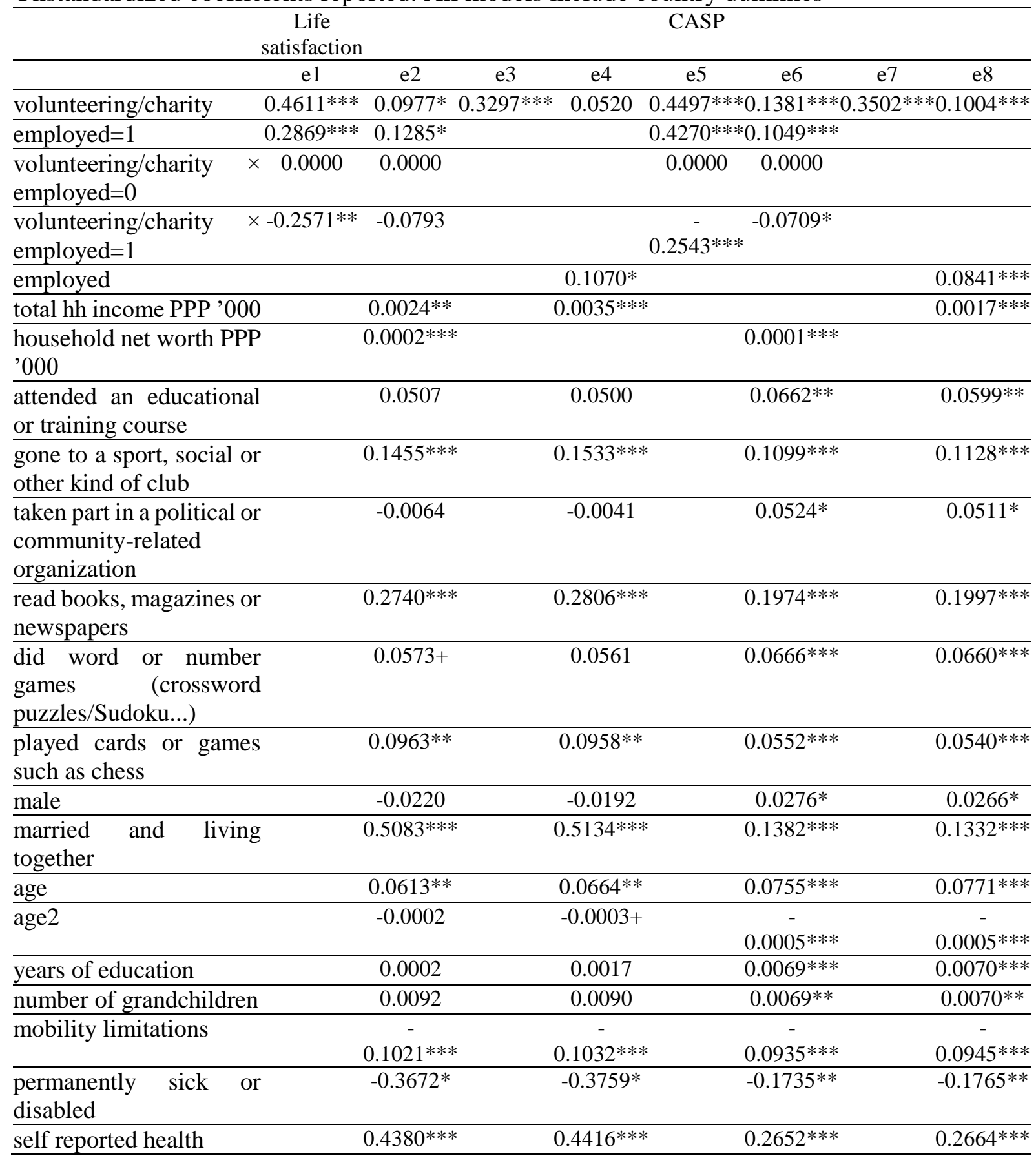


RECENT ISSUES IN ECONOMIC DEVELOPMENT

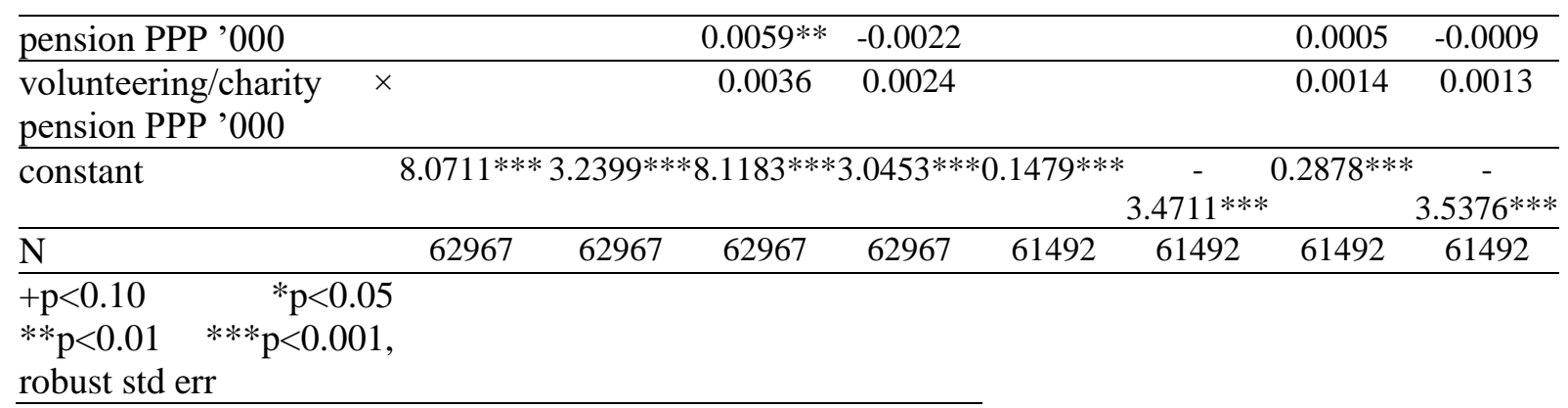

Source: own compilation

For robustness we attempted pooling waves together in order to use panel data techniques such as fixed effects to account for unobserved personal characteristics that arguably affect volunteering (Meier \& Stutzer, 2008b). First, there are only 5 waves $^{12}$ available, as compared to more than a dozen in the German Socio-Economic Panel (GSOEP) or British Household Panel Survey (BHPS). Second, country coverage varies substantially across waves. More problematically, there is little overlap across persons, unfortunately. Astonishing more than half of respondents from wave 4 does not match wave 5, and about half of respondents from 5 does not match wave $6 .{ }^{13}$ Therefore, we conclude that there is little point in using panel techniques. Indeed, this is what the literature argues, too. For instance, "with high attrition rates, however, the number of cases in the panel decreases quickly, thus reducing the base for longitudinal analyses" (Blom \& Schröder, 2011).

\section{Appendix}

\section{Welfare contributions}

Contributions differ widely: see table 12 (for OECD countries) and for more discussion see OCDE (2013) and Vidlund and Bach-Othman (2009).

Table 12. Pension contribution rates (employee and employer), 2012, as percent of income

\begin{tabular}{lccc}
\hline & Sum & Employee & Employer \\
\hline Austria & 22.8 & 10.3 & 12.6 \\
\hline Belgium & 16.4 & 7.5 & 8.9 \\
\hline Czech Republic & 28.0 & 6.5 & 21.5 \\
\hline Denmark* & & & \\
\hline Estonia & 22.0 & 2.0 & 20.0 \\
\hline Finland & 22.8 & 5.2 & 17.7 \\
\hline France & 16.7 & 6.8 & 9.9 \\
\hline Germany & 19.6 & 9.8 & 9.8 \\
\hline Greece & 20.0 & 6.7 & 13.3 \\
\hline Hungary & 34.0 & 10.0 & 24.0 \\
\hline Ireland+ & & & 23.8 \\
\hline Italy & 33.0 & 9.2 & 8.0 \\
\hline Luxembourg & 16.0 & 8.0 & \\
\hline
\end{tabular}

12 Wave 3 (SHARELIFE) is not comparable to others and is not really a wave per se.

13 This may be also due to the addition of new respondents in subsequent waves. The study covers the 50+ population, so in each new round SHARE needs to add new observations. In some countries, an attempt was made to try to find more money for research. For example, in Poland round 7 will count probably 5000 people, that is, it will increase almost twice. 
RECENT ISSUES IN ECONOMIC DEVELOPMENT

\begin{tabular}{lccc}
\hline Netherlands & 17.9 & 17.9 & 0.0 \\
\hline Poland & 19.5 & 9.8 & 9.8 \\
\hline Portugal+ & 18.0 & 4.0 & 14.0 \\
\hline Slovak Republic & 24.4 & 15.5 & 8.9 \\
\hline Slovenia & 28.3 & 4.7 & 23.6 \\
\hline Spain & 18.4 & 7.0 & 11.4 \\
\hline Sweden & & & \\
\hline United Kingdom+ & & & \\
\hline Iceland+ & & & 4.9 \\
\hline Norway+ & 9.8 & 4.9 & 11.0 \\
\hline Switzerland & 20.0 & 9.0 & 20.0 \\
\hline Turkey & & & 5.0 \\
\hline Australia* & 31.0 & 11.0 & 20.0 \\
\hline Brazil & 9.9 & 5.0 & 12.0 \\
\hline Canada & 28.0 & 8.0 & 8.4 \\
\hline China & 24.0 & 12.0 & 4.5 \\
\hline India & 16.8 & 8.4 & \\
\hline Japan & 9.0 & 4.5 & 22.0 \\
\hline Korea & & & 6.2 \\
\hline Mexico* & & & \\
\hline New Zealand! & 22.0 & 0.0 & \\
\hline Russian Fed & 10.4 & 4.2 & \\
\hline United States & & & \\
\hline
\end{tabular}

$*=$ Private pension contributions only

$+=$ No separate pension contribution

$!=$ No contributions

Source: own compilation. OECD Pensions at a Glance 2013, p. 169, based on OECD (various years), Taxing Wages; OECD (2013), Revenue Statistics; Social Security 